\title{
Small- and Medium-sized Firms' Internationalization and Performance during a Recession
}

\author{
Yong-Young KIM${ }^{1}$, Young Ei KIM${ }^{2}$, Ka Young $\mathrm{OH}^{3}$
}

Received: June 29, 2020 Revised: July 19, 2020 Accepted: August 10, 2020

\begin{abstract}
This study aims to verify the relationship between overseas activities and performance of Korea's SMEs during the last financial crisis. Whether overseas activity performance of enterprises differed was determined based on characteristic variables, including the degree of concentration on R\&D and marketing. This study also examined how SMEs' international transactions and their performance differed based on internal variable such as the level of stock holding and firm size. This study developed a model for analyzing the relationship between the level of internationalization and performance of Koran SMEs listed in the KOSDAQ. We used firm-level data, including annual reports and various data sources such as the KISVALUE program. To smooth annual fluctuations in accounting data, we used a three-year average from 2006 to 2009 for each variable in the study. The results showed that proactive overseas activities ultimately had a positive effect on an enterprise's performance, even though it initially had a negative effect. Therefore, enterprises should focus their capacity on R\&D and marketing environment. Although numerous studies have focused on the relationship between overseas activities and performance of enterprises, the present study analyzed whether enterprises should continuously engage in overseas activities and what capacities they should strengthen during a global economic recession.
\end{abstract}

Keywords: External, Global Recession, Internationalization, Small- and Medium-sized Firms

JEL Classification Code: M13, M16, M41

\section{Introduction}

It is extensively accepted that to increase performance, firms should engage in international transaction by means of exporting, foreign direct investment (FDI), and international mergers and acquisitions (M\&A). Prior studies have presented that a firm's sales, profit, stock value, return on equity (ROE), and return on asset (ROA) can increase as the firm commences international transaction (Eckert et al.,

${ }^{1}$ First Author. Associate Professor, Business Administration, Konkuk University Glocal Campus, Republic of Korea.

Email: kyyoung@kku.ac.kr

${ }^{2}$ Professor, Department of Business Administration, Seoul Digital University, Republic of Korea. Email: kimyei@naver.com

${ }^{3}$ Corresponding Author. Associate Professor, Economics and Trade,

Konkuk University Glocal Campus, [Postal Address: 268 Chungwon-

daero, Chungju-si, Chungcheongbuk-do, 27478, Korea]

Email: ohkayoung@kku.ac.kr

(c) Copyright: The Author(s)

This is an Open Access article distributed under the terms of the Creative Commons Attribution Non-Commercial License (https://creativecommons.org/licenses/by-nc/4.0/) which permits unrestricted non-commercial use, distribution, and reproduction in any medium, provided the original work is properly cited.
2010; Gupta \& Misra, 2000). In addition, these studies have shown that a firm's long-term performance increases with the passage of time if the amount or scope of its investment in international transaction rises, even if its international transaction initially has a negative effect on the firm's performance.

In general, doing business internationally is susceptible to the world economy's conditions. Firms would waver on international transaction during an economic recession. Countries with small and open economy system such as Korea would respond sensitively to the world economic situations. In fact, Korea's outward FDI has shown an upward trend from $\$ 565.3$ billion in 2000 to $\$ 2.1$ trillion in 2007 and a downward trend to $\$ 1.9$ trillion in 2008 because of the global financial crisis. This downward trend has continued until 2015. In addition, the ratio of direct investment in foreign countries decreased in 2008 before exhibiting an upward trend once again. Accordingly, there has been a downward trend in firms' international transaction during a recession period of the world economy.

Numerous studies have determined the characteristics of either a region or an enterprise by investigating the 
relationship between a firm's international transaction and its performance. Previous studies have verified the relationship between a firm's international transactions and its performance and have found that there are both positive and negative results (Grant, Jammine, \& Thomas, 1988; Kim, Hwang, \& Burgers, 1989; Tallman \& Li, 1996). To investigate the relationship between a firm's international transaction and its performance, our study examine SMEs international transactions in two dimensions: (1) export sales volume and (2) the level of foreign investment in fording countries by means of FDI and/or international M\&A. We assess ROA as a factor measuring an SME's performance and determine how an SME's exports and foreign investment differ based on firm characteristics. In addition, we examine firm characteristics such as the degree of marketing expenses ratio of R\&D, firm size, and the degree of stocks held.

Prior studies investigating the relationship between a firm's internationalization and its performance have revealed U-shaped or inverted U-shaped relationships (Contrator, Kundu, \& Hsu, 2003; Lu \& Beamish, 2004; Ruigrok \& Wagner, 2003). These studies have focused only on the relationship between performance and foreign expenses or initial learning costs. They have little considered the external environments such as international recession, which could not be controlled by individual firms. Therefore, it is vital to investigate whether continuous international transaction benefits a firm facing an unfavorable situational environment are insufficient.

As mentioned above, whether firms in Korea with a small and open economy should continue international transactions is a question of necessity rather than choice. Determining the scope and depth of an appropriate level of international transactions when the world economy encounters a recession is very important. Small- and medium-sized enterprises (SMEs) are relatively small in scale. They differ from large corporations in their direct susceptibility to external environments. Therefore, an analysis could be performed on what an SME needs to focus on under uncertain environments.

Against this backdrop, we attempted to verify the relationship between a Korean SME's international transactions and its performance. By analyzing Korean SMEs' activities during the global financial crisis, we attempt to investigate the effects of international transactions on firm performance. Concurrently, our study intend to deduce firm characteristics and determine factors affecting performance. Our study intends to determine whether an SME's level of internationalization has a positive effect on its performance despite the burden of initial learning costs during a global recession period.

The core research question of our study is: Should an enterprise continuously engage in overseas activities even when the economic situation is not good? We attempt to provide empirical evidence to the hypothesis that continuous internationalization resolves the problem of shrinking the domestic market in a country such as Korea with a small and open economy. Our study can provide important contributions. First, it is possible to find implicative meaning about which characteristics of an SME should be focused on in order to achieve positive performance through overseas activities in an external environment over which they have no control. Second, our study referred to preceding studies in the literature to deduce factors affecting an enterprise's performance.

The remainder of our study is structured in the following manner. The following chapter presents hypothesis development. Next, the research method of our study is described. The result of an analysis is then shown. Finally, our study concludes by discussing research results.

\section{Hypothesis Development}

\subsection{Internationalization and Performance}

\subsubsection{Export Sales Volume}

The literature has provided several theoretical explanations for the nature of internationalizationperformance relationship such as positive, negative, U-shaped and invert U-shaped. Several studies have found support for a positive and linear relationship between internationalization and performance (Grant, 1987; Grant, Jammine, \& Thomas, 1988; Kim, Hwang, \& Burgers, 1989; Tallman \& Li, 1996). These empirical results have indicated that, as a firm expands its business into a foreign country, there could be a positive and linear impact on firm performance. Other researchers have found evidence for a U-shaped relationship between internationalization and firm performance (Ruigrok \& Wagner, 2003). Liabilities of foreignness may result from the fact that firms are not local firms, but foreign ones. A host-country government may discriminate against foreign firms and create favorable business environment for its local firms.

It is posited that the slope of the curve is initially positive. After it reaches an apex, it becomes negative because greater geographic dispersion increases the cost of coordinating, integrating, and managing multinational firm's overall operations. Gomes and Ramaswamy (1999) indicated that the internationalization-performance relationship is nonlinear, first rising, then declining as costs eventually overtake the benefit of internationalization.

Another suggestion began to be put forward. Hitt, Hoskisson and Ireland (1994) contended that the relationship between internationalization and performance has an inverted shape. Taylor (1988) performed research targeting U.S. companies and pointed out that a foreign exposure positively 
influences performance. That is, internationalization would create opportunities to improve performance. Therefore, we developed the following hypothesis:

H1-1: The relationship between an SME's internationalization and its performance is U-shaped, with a negative slope at low levels of exporting and positive at a high level of exporting.

\subsubsection{Foreign Investment Level}

Duncan and Mtar (2006) suggested that the existence of foreign experience before an organization acquires a relevant company would have a positive influence on the acquisition. Porrini (2004) investigated whether acquirers' and targets' alliance experiences are beneficial to creating value in high- and low-tech firm acquisitions and found that alliance experience is correlated with market returns. Meschi and Metais (2006) studied a French acquisition in the United States and found that acquisition experience is associated with performance. This is because experience can reduce the uneasiness of shareholders to a foreign acquisition. In addition, Vo (2019) explored the relationship between the export performance and the stock return of Vietnamese companies and indicated that the export growth has a positive effect on the stock return. Therefore, we developed the following hypothesis:

H1-2: The relationship between an SME's internationalization and its performance is inverted and $U$-shaped, with a slope being positive at low degrees of foreign activities but negative at high degrees of foreign activities.

\subsection{Firm Resources}

Adaptability to a rapidly changing external economic environment may differ based on firm characteristics. These characteristics of an SME may become the competitive advantage that allows it to survive in an external environment that it has no control. This might be ultimately connected to the SME's performance. Accordingly, we employed R\&D expense, marketing expense, and firm size as the elements of an SME's characteristics.

\subsubsection{R\&D Intensity}

R\&D belongs to intangible property. It seems to be viewed as the best approach to obtain a comparative advantage among businesses. It increases the competitive power of a firm where there is unlimited competition. After exploring various fields such as firm size, industry sectors, and the level of technology, previous studies have explained that $R \& D$ expenditure has a significant and positive effect on an abnormal return, even though the return is insignificant. It is widely accepted that a firm's value creation does increase the stock market when it announces an increase in accordance with $R \& D$, even though this has low profitability return for the firm. Merchant and Schendel (2000) asserted that a positive influence of the proportion of $R \& D$ can influence international joint ventures. Jones and Danbolt (2003) examined the stock market's reaction to research and development (R\&D) announcements made by listed British firms and found that $R \& D$ projects are associated with significant positive abnormal returns if the information related to R\&D announcement contains modest new information about the company's future earnings. Qian (2002) indicated that R\&D expenditure plays a significant role in explaining profitability. Binh and Tung (2020) also founded that the R\&D expenditure has a positive significant effect on output growth of organization. That is, if a firm participates or invests in R\&D at a high rate, it might be able to present new products in the market place more frequently. Therefore, we developed the following hypotheses:

H2-1: The effect of internationalization on firm performance would be stronger for a firm with higher $R \& D$ intensity than a firm with lower intensity.

H2-2: $R \& D$ intensity can moderate the relationship between foreign activities and performance in a way that high levels of $R \& D$ intensity negatively act in the first stage and positively act in the second stage.

\subsubsection{Marketing Intensity}

Marketing efforts of a multinational firm are routinely operationalized by their advertising intensity (Caopn, Parley, \& Hoenig, 1990) as firms are reluctant to disclose their total marketing expenditures. In our study, advertising intensity was employed as a surrogate for a Korean multinational firm's marketing efforts. Just as data on all marketing activities are not always available, so we were not able to employ the ratio of a firm's marketing expenditures to its total sales as one indicator of marketing efforts. In general, marketing capability is needed to support manufacturing/sales of products or services more efficiently. It also enables the firm to be differentiated from competitors to establish a firm's own brand image (Tseng et al., 2007). It is often defined as advertising intensity (Gatignon \& Anderson, 1988). Qian (2002) has empirically examined individual and joint effects of internationalization and product diversification on profit performance using marketing intensity as a control variable and found that this marketing intensity variable has a positive influence on performance without statistical significance. Eckert et al. 
(2010) have found that advertising is a considerable variable in internationalization of firm. Therefore, we developed the following hypotheses:

H3-1: The effect of internationalization level on performance would be stronger for a firm with higher marketing intensity than for one with lower marketing intensity.

H3-2: Marketing intensity would moderate the relationship between exporting level and performance in a way that high levels of marketing intensity negatively act in the first stage and positively act in the second stage.

\subsubsection{Firm Size}

Firm size is a common variable related to firm performance (Contractor, Kundu, \& Hsu, 2003). Contractor, Kundu and Hus (2003) have used firm size measured by the number of employees as controlling variable and found that firm size had positive influence on performance of firms. Meschi and Metais (2006) have also used the relative size of acquired company as a control variable. In their study, size is estimated based on annual sales. They determined the impact of an announcement on US foreign investment on performance and found that the size of the acquirer had a negative effect on abnormal returns. Their result is similar to results of other studies (Merchant \& Schendel, 2000). That is, the greater the size of the firm, the more suitable the firm for international activities which can influence cumulative abnormal return. Therefore, we developed the following hypotheses:

H4-1: The effect of internationalization on performance would be stronger for a firm with bigger size than a firm with smaller size.

H4-2: Firm size can moderate the relationship between exporting and performance.

\section{Research Methods}

\subsection{Sample}

The sample of our study was drawn from ventures listed in the KOSDAQ. We only selected firms with vigorous export and foreign activities because our main purpose was to analyze the relationship between internationalization and performance based on sales volumes. We used firmlevel data, including annual reports and various data sources such as the KISVALUE program. To smooth annual fluctuations in accounting data, we used a threeyear average from 2006 to 2009 for each variable in the study, excluding previous experience such as establishing foreign subsidiaries.
Table 1: Sample Characteristics

\begin{tabular}{|l|l|}
\hline Industry Type & N \\
\hline Chemical & 35 \\
\hline Foods and Spirits & 20 \\
\hline Pharmaceuticals & 20 \\
\hline Automotive Components & 30 \\
\hline Industrial Equipment & 28 \\
\hline Instruments-Medical & 15 \\
\hline Devices & 13 \\
\hline Appliances & 30 \\
\hline Telecommunications & 15 \\
\hline Steel & 15 \\
\hline Information Technology & 15 \\
\hline
\end{tabular}

Finally, 236 firms were sampled. Descriptive statistics for all sample firms is shown in Table 1. Industry characteristics used in our study are specified as follows: chemicals and advanced materials, 35 industries; restaurant business, 20 industries; pharmaceutical, 20 industries; motor vehicle and parts, 30 industries; instruments -medical, 15 industries; devices, 13 industries; telecom fixed line, 15 industries; and steel, 15 industries.

\subsection{Measures}

Internationalization as a dependent variable refers to the extent to which a firm expands cross-border. In our study, DOI was counted through two measures: (1) the ratio of sales by exporting to total sales and (2) the ratio of sales by foreign activities to total sales. Foreign activities are often measured by the number of foreign subsidiaries. However, we regarded international strategic alliances and M\&A as a firm's foreign activities.

Firm performance as a dependent variable was measured as return on assets (ROA). It was calculated by dividing operating returns by total assets. Performance has been operationalized in past studies using accounting based, market based, and operational measures. Operational variables such as market share and product quality have been suggested to reflect a firm's 'fundamentals' accurately (Venkatraman and Ramanujaam, 1986). In our study, we used ROA as an appropriate performance measure.

Following previous studies (e.g., Geringer, Beamish, \& Da Costa., 2000; Tallman \& Li, 1996), we included several variables, including R\&D and marketing intensity as independent variables. It should be controlled in the research model. The most representative internal capability is related to technology and marketing (Kogut and Chang, 1991; Barney, 1991). R\&D intensity usually implies a firm's 
internal efforts to gain and create knowledge. Extant research has shown a positive relationship between R\&D intensity and performance in a firm (Delios \& Beamish, 1999; Kotabe, Srinivasan, \& Aulakh, 2002). Therefore, we need to control $\mathrm{R} \& \mathrm{D}$ intensity. It could be assessed as the ratio of $\mathrm{R} \& \mathrm{D}$ to total sales. Dependent and independent variables used in our study are summarized in Table 2 .

\subsection{Model Development}

We used a multiple and moderate regression as a fitting model to test our hypotheses considering the following: (1) the measure between performance and the level of internationalization, (2) the interval scale used to gauge the dependent variable, and (3) the need to include moderating effects. Specifically, we applied the following specification of a regression model:

$$
\begin{aligned}
& \mathrm{Y}=\mathrm{a}+\mathrm{b} 1 \mathrm{DOI} i+\mathrm{b}_{2} \mathrm{DOI}^{2} i+\mathrm{b} 3 \mathrm{DOE} i+\mathrm{b}^{2} \mathrm{DOE}^{2} i \\
& +\mathrm{b} 5 \mathrm{R} \& \mathrm{D} i+\mathrm{b} 6 \mathrm{MAR} i+\mathrm{b} 9 \mathrm{SS} i+\mathrm{b} 10 \mathrm{SIZE} i \ldots \ldots+\varepsilon
\end{aligned}
$$

\section{Results}

\subsection{Main Effects}

Results of correlation for all variables used in our study are shown in Table 3 . None of the correlation coefficient was significant to estimate the regression equation. Such low correlations indicate that there would be sufficient independent variation among these variables employed in our study, thereby allowing discrete effects for an estimation. In our study, the correlation between firm size and marketing intensity was very high at .341 . To investigate how performance change was related to DOI_1 explained by foreign sales, we used multiple regression. DOI_1 was employed for a liner term from quadratic term. It appears that the correlation between them is substantially high in the sense that they are derived from the same variable. At first, in Model 1, we attempted to explicate the relationship between a firm's level of internationalization and performance by DOI 1 and DOI 12 functions.

Model 1 shows that the relationship between a firm's foreign sales ratio and its performance had a negative impact on performance, although it was statistically insignificant. However, in the case of variable adopted by changing firm's foreign sales ratio to DOI_12, the t-value was 4.078 which was statistically significant, indicating a positive influence on the firm's performance. In other words, from model 1, we found that firm's foreign sales ratio and performance had a U-shaped relationship. Nonetheless, it seems unreasonable to consider it as a perfect $U$ shaped in the sense that the shape seems to be almost parallel. It begins to rise slowly when a firm's foreign sales arrives at $40 \%$. It then increases abruptly when foreign sales ratio hits $80 \%$.

Table 2: List of Variables

\begin{tabular}{|l|l|l|l|}
\hline Variables & & \multicolumn{1}{c|}{ Indicators } & \multicolumn{1}{c|}{ Operational Definition } \\
\hline Performance & DOI_1 & Export Sales Volume & The average of foreign sales/total sales \\
\hline & DOI_2 & Foreign Activities & $\begin{array}{l}\text { The average of strategic alliances, M\&A, establishing foreign } \\
\text { subsidiaries from 2006 to 2009 }\end{array}$ \\
\hline Firm Resources & R\&D_INT & R\&D Intensity & $\begin{array}{l}\text { The average of the ratio of R\&D expenditures to total sales from } \\
2006 \text { to 2009 }\end{array}$ \\
\hline & MAR_INT & Marketing Intensity & $\begin{array}{l}\text { The average of the ratio of marketing expenditures to total sales } \\
\text { from 2006 to 2009 }\end{array}$ \\
\hline Controls & SIZE & Firm Size & The average of total number of employees from 2006 to 2009 \\
\hline
\end{tabular}

Table 3: Correlation Matrix

\begin{tabular}{|l|c|c|c|c|c|c|}
\hline & DOI_1 & DOI_2 & MAR & R\&D & SIZE & ROA \\
\hline DOI_1 & 1.000 & $.180^{*}$ & $-.142^{*}$ & .046 & .021 & .013 \\
\hline DOI_2 & & 1.000 & $.286^{* *}$ & -.001 & .252 & -.029 \\
\hline MAR & & & 1.000 & -.039 & $.361^{* * *}$ & -.005 \\
\hline R\&D & & & & 1.000 & -.115 & -.022 \\
\hline SIZE & & & & & 1.000 & .095 \\
\hline ROA & & & & & & 1.000 \\
\hline
\end{tabular}

Notes: ${ }^{*}$ Correlation is significant at the 0.05 level, ${ }^{* *}$ Correlation is significant at the 0.01 level, ${ }^{* * *}$ Correlation is significant at the 0.001 level. 
$\mathrm{ROA}=2.969-\beta 12.599+\beta 4.100+\varepsilon$

Model 1

This strategy is particularly applicable to internationalization of SMEs because SMEs frequently lack resources for foreign direct investments (Dalli, 1995; Zahra, Neubaum, \& Huse, 1997). It also gives them an opportunity to obtain valuable foreign experience (Root, 1994; Zahra, Neubaum, \& Huse, 1997; Erminio \& Rugman, 1996). Ngo et al. (2020) indicated that trade openness has a negative effect on FDI inflow. In the beginning of exporting, a firm could achieve a negative performance. Nevertheless, as exporting increases, it changes from negative to positive. This is because in the early stage of exporting, affiliate network is not built yet. Accordingly, we see that there is a U-shaped relationship between exporting and firm performance (see Table 4).

There is a turning point where the effect of internationalization on firm performance changes from negative to positive. Such result implies that, in Model 1 (internationalization is examined by exporting sales), Korean SMEs' internationalization seems to create a U-shaped relationship with firm performance (see Table 5).

When exploring the relationship between internationalization and performance of international transactions in SMEs, exporting and various firm's foreign activities are two most prominent avenues of internationalization.

Table 4: Relationship between DOI_1 and Performance

\begin{tabular}{|l|c|c|c|}
\hline Variables & Beta & t-Value & Sig. \\
\hline Constant & .204 & 2.969 & .000 \\
\hline DOI_1 & -.001 & -2.599 & .116 \\
\hline DOI_2 & .000 & 4.100 & .000 \\
\hline $\mathrm{R}^{2}$ & & .011 & \\
\hline $\mathrm{F}$ & & 1.244 & \\
\hline $\mathrm{N}$ & & 236 & \\
\hline
\end{tabular}

Table 5: Relationship between DOI_2 and Performance

\begin{tabular}{|l|c|c|c|}
\hline Variables & Beta & t-Value & Sig. \\
\hline Constant & .204 & 4.055 & .000 \\
\hline DOI_1 & .082 & 1.577 & .116 \\
\hline DOI_2 & -.011 & -1.434 & .153 \\
\hline $\mathrm{R}^{2}$ & & .011 & \\
\hline $\mathrm{F}$ & & 1.244 & \\
\hline $\mathrm{N}$ & & 236 & \\
\hline
\end{tabular}

In Model 1, we used exporting sales to measure the linear term of internationalization. In the first stage, exporting is shown to have a negative effect on firm performance. However, in the second stage, exporting has a positive effect on firm performance. We can see that the relationship between exporting and firm performance has a U-shaped relationship. In Model 2, we used foreign activities to measure the squared term of internationalization. In the first stage, foreign activities are shown to have a positive effect on firm performance. In the second stage, they are presented to have a negative effect on firm performance. Therefore, the relationship between a firm's foreign activities and firm performance has an inverted U-shaped relationship. In other words, the shape of their relationship can be influenced by different variables. Both shapes indicate that exporting has a negative impact on firm performance in the early stage. However, in the second stage, it has a positive impact on firm performance by reducing product cost and marketing cost with increasing network of foreign affiliates.

However, in Model 2, squared term of internationalization has a negative impact on firm performance. This implies that the benefits and transaction costs of internationalization could cancel each other out. That is, it is critical to determine the optimal level at which a firm can maximize its internationalization benefits. The relationship between Internationalization and Control Variables can be expressed as follows:

ROA $=4.055+1.577 *$ DOI_2-1.434*(DOI_2) ${ }^{2}+\varepsilon \quad$ Model 2

Table 6 presents the results of Model 1 and Model 2. Model 1 uses exporting to measure the linear term of internationalization while Model 2 uses firm's international transactions to measure the squared term of internationalization. A model having input of control variables simultaneously can lead to more explanations between internationalization and performance. In Model 1, firm size is shown to have a significant and a positive influence on firm performance. However, Adjusted R is increased from .193 to .230 while F-value is decreased from 17.539 to 16.394. In Model 2, firm's foreign activities are presented to hold a negative impact on performance, even though the effect is statistically insignificant. In Model 2, a linear term of exporting is presented to hold a significant effect on firm performance with t-value of 1.802. The squared term of a firm's foreign activities is presented to hold a negative impact on firm performance with a t-value of -1.953. The model fit changes from 0.106 to 0.121 and the F-value also is decreased from 8.672 to 7.541 . Therefore, the model of DOI_1 with squared terms has higher explanation than DOI_ 2 model. 
Table 6: Firm Size

\begin{tabular}{|l|c|c|c|c|}
\hline & DOI_1 & DOI_1 & DOI_2 & DOI_2 \\
\hline Intercept & $-2.128(.034)$ & $.551(.582)$ & $1.440(.151)$ & $.699(.485)$ \\
\hline DOI_1 & $4.919(.000)$ & $-1.801(.073)$ & & \\
\hline DOI_12 & & $3.264(.001)$ & & \\
\hline DOI_2 & & & $-.040(.542)$ & $1.802(.050)$ \\
\hline DOI_2 & & & & $-1.953(.052)$ \\
\hline R\&D & $-.046(.964)$ & $-.317(.751)$ & $.013(.840)$ & $.080(.936)$ \\
\hline SIZE & $5.183(.000)$ & $4.479(.000)$ & $.334(.000)$ & $5.208(.000)$ \\
\hline Adj. $R^{2}$ & .193 & .230 & .106 & .121 \\
\hline F & $17.539(.000)$ & $16.394(.000)$ & $8.672(.000)$ & $7.541(.000)$ \\
\hline $\mathrm{N}$ & 236 & 236 & 236 & 236 \\
\hline
\end{tabular}

Notes: The numbers indicate t-talues, ( ) indicates significant probability.

Table 7: High R\&D Intensity

\begin{tabular}{|l|c|c|c|c|}
\hline & \multicolumn{4}{|c|}{ Unstandardized Coefficient (t-Value) } \\
\hline DOI 1 & $3.214(.009)$ & $-.187(.649)$ & & \\
\hline DOI 1 & & $3.449(.001)$ & & $-1.538(.230)$ \\
\hline DOI 2 & & & $-.454(.775)$ & $4.521(.000)$ \\
\hline DOI 2 & & & & $-.529(.598)$ \\
\hline R\&D & & $-1.257(.587)$ & $-.410(.683)$ & $3.181(.002)$ \\
\hline SIZE & $-1.296(.487)$ & $3.780(.001)$ & $3.120(.002)$ & .129 \\
\hline $\mathrm{R}^{2}$ & $5.990(.000)$ & .457 & .117 & .101 \\
\hline Adjusted $\mathrm{R}^{2}$ & .541 & .160 & .056 & 3.1211 \\
\hline F-value & .156 & 9.256 & 3.405 & 115 \\
\hline $\mathrm{N}$ & 11.254 & 115 & 115 & \\
\hline
\end{tabular}

\subsection{Moderating Effects of Firm Resources}

To examine themoderating effect of corporatecapability on the relationship between squared term of internationalization and performance, we determined firm's ability variables of R\&D intensity and size. A firm's multinational model can be explained differently depending on the firm's ability variables. In essence, firms can attain differential outcomes of international expansion on the basis of their resources to maximize the benefits of internationalization while reducing relevant costs of expansion. We posit that $\mathrm{R} \& \mathrm{D}$ and size are two drivers that would enable a firm to attain greater benefits of internationalization. Several previous studies (Hufbauer, 1970; Mansfield, 1981; Kotabe, 1990) have found a positive relationship between $\mathrm{R} \& \mathrm{D}$ intensity and firm performance. Companies can improve their performance by focusing on product design/development and by improving their manufacturing processes (Kotabe, 1990).

\subsection{Research and Development Expenses}

Results of moderated regression analysis divided into two model groups relevant to the firm's R\&D degree are shown in Table 7. The first Model (DOI_1, DOI_12) considers firm's multinational degree as exporting sales while the second model (DOI_2, DOI_2 ${ }^{2}$ ) considers internationalization of the firm as foreign activities.

The difference between the two groups was testified by $\mathrm{R}^{2}$ 's alteration. In the event that we see the model that represents a group with high $\mathrm{R} \& \mathrm{D}$ intensity degree and consider the firm's internationalization as exporting activity, $\mathrm{R}^{2}$ of each model (DOM1 and DOI_ $1^{2}$ ) is increased from 0.156 to 0.160 . In the case of DOI_ 1 's linear model, this value is statistically insignificant with negative influence. However, in the case of DOI_1's squared model, t-value is 3.449 and p-value is 0.001 . This means that there is a positive influence. Furthermore, the models that consider 
a firm's internationalization degree as foreign activities, $\mathrm{R}^{2}$ of DOI 2 model is increased from 0.056 to $0.101 \mathrm{In}$ the case of DOI_2's linear model, its t-value is -1.538 , a statistically insignificant number with negative influence. On the contrary, in the case of DOI_2's squared model, $\mathrm{t}$-value is 4.521 with a positive influence, showing an inverted U-shaped relationship. Nevertheless, these results indicate that firm's higher internationalization degree does not decrease its performance.

In the case of model DOI_ $1^{2}$ of firm's exporting sales, $\mathrm{U}$ shaped relationship between internationalization and performance of the firm is observed. On the other hand, in the case of Model DOI_2's linear term which considers internationalization as foreign activities, there is a pattern close to be parallel. In the case of squared term, there is a slightly increase in the shape of the figure from the point of $20 \%$. Therefore, there is no sign of performance decrease when there is an increase in the degree of internationalization of the firm with high R\&D level. Therefore, Hypothesis 2-2 is supported.

\section{Conclusions and Implications}

The main goal of our study was to investigate the relationship between firm's internationalization degree and performance. Based on firms registered in the Korean KOSDAQ with overseas exports and overseas activities, we performed our study using two main factors such as R\&D intensity and size reflecting the degree of internationalization of SMEs. To investigate how performance change is related to DOI_1 explained by foreign sales, we used multiple regression. DOI_1 was used as linear term and quadratic term. We also suggested model DOI_2 measured by foreign activities such as FDI, M\&A, overseas affiliates, and others.

Using Model 1, we tried to explicate the relationship between a firm's internationalization degree and Performance by DOI_1 and DOI_12 functions. In Model 1 , firm's exporting sales ratio has a negative influence on performance, although it is statistically insignificant. However, in the case of variable proposed by changing firm's exporting sales ratio to DOI_1 ${ }^{2}$, the t-value is 1.695 which is statistically significant, indicating a positive influence of exporting sales on the firm's performance. That is, they have a U-shaped relationship. Model 2 employed a firm's foreign activities. It was found that the firm's foreign activities had a positive influence on firm performance. But in second stage of Model 2, t-value was -6.226, indicating a negative impact on firm performance. This influence was statistically significant. Furthermore, in Model 2, the linear term of internationalization seems to be going parallel while the squared term of internationalization was presented to decline slowly when firm's foreign activities reached $20 \%$. It then decreased abruptly when firm's foreign activities reached 30\%. This means that internationalization measured by a firm's foreign activities could be an inverted U-shaped relationship with any performance.

In addition, our study verified the moderate effect of firm's internal capability such as R\&D and size of firm. Firm size was employed as a control variable because it could affect firm performance. The bigger the firm size, the higher the performance. Furthermore, we may assume that, the larger the firm size, the more effectual the role of information networking in the firm's operation. Moreover, we verified the moderating effects of firm resources on the relationship between internationalization and firm performance. Moderating variables were $R \& D$ intensity and marketing intensity. In Model 1 using exporting as measurement of internationalization, high level of $R \& D$ had a negative impact on firm performance in the first stage, although the effect was statistically insignificant. However, in Model 2 using foreign activities as measurement of internationalization, although high level of R\&D had a negative effect on firm performance in the first stage, it had a positive influence on firm performance in the second stage.

Findings of our study have the following contributions. It provides useful insights for practitioners. We explored the pattern between internationalization and performance for Korean Ventures SMEs. The core question of our study is: Should an enterprise continuously engage in overseas activities even when the economic situation is not good? The answer to this question is "yes". After analyzing the amount of export activity in an enterprise's sales and overseas activities while carrying out tasks of our study, our results showed that higher amounts of overseas activities had positive influence on an enterprise's performance. This provides empirical evidence to the hypothesis stating that continuous overseas activities can resolve the situation of a shrinking domestic market in countries like Korea with small open economy. Our study also has managerial implications. First, we verified how to access internationalization of firms. Exporting sales have a positive influence on firm performance. However, deep foreign activities such as FDI, international M\&A, establishing a subsidiary overseas, and international strategic alliances negatively affect performance in squared term. Therefore, strategic access for Korean Ventures SMEs' internationalization is needed.

Internationalization has been a critical issue for many firms and their managers in the sense that it could provide them with good opportunities. However, it also incurs high transaction costs, including coordination costs, communication costs, and costs to manage diversities. Transaction costs vary substantially depending on the number of regions and countries in which a firm does business and the number of product lines that the firm has carried. Accordingly, international managers should be 
aware of these transaction costs while they select an entry mode of internationalization.

Second, our study presented practical guidance for international managers in a firm. Our findings pointed out that these managers should have a long-term perspective of internationalization. In the initial stage of internationalization, a firm could not achieve a positive performance immediately from a foreign expansion. Such a firm could suffer a decline in profits in the stage. Nonetheless, during this stage, declining profits should not be an obstacle of internationalization efforts. In the stage, managers should devote their commitments to ameliorating initial disadvantages to drive intrinsic benefits of internationalization to arise which will eventually improve firm performance.

During early stages of international expansion, managers need to be resolute and cognizant of the potential downside of excessive international expansion. They need to be proactive in the design and implementation of international strategies by optimizing the configuration of subsidiary networks to keep the scope of internationalization activities at an optimal level (Lu and Beamish, 2004).

\section{References}

Barney, J. (1991). Firm Resources and Sustained Competitive Advantage. Journal of Management, 17(1), 99-120.

Binh, Q. M. Q., \& Tung, L. T. (2020). The Effect of R\&D Expenditure on Firm Output: Empirical Evidence from Vietnam. Journal of Asian Finance, Economics and Business, 7(6), 379-385. https:// doi.org/10.13106/jafeb.2020.vol7.no6.379

Capon, N., Parley, J. U., \& Hoenig, S. (1990). Determinants of Financial Performance: A Meta-analysis. Management Science, $36,1143-1158$.

Contractor, F. J., Kundu, S. K., \& Hsu, C. C. (2003). A Threestage Theory of International Expansion: The Link between Multinationality and Performance in the Service Sector. Journal of International Business Studies, 34(1), 5-18.

Dalli, D. (1995). The Organization of Exporting Activities: Relationships between Internal and External Arrangements. Journal of Business Research, 34(2), 107-115.

Delios, A., \& Beamish, P. W. (1999). Geographic Scope, Product Diversification, and the Corporate Performance of Japanese Firms. Strategic Management Journal, 20(8), 711-727.

Duncan, C., \&. Mtar, M. (2006). Determinants of International Acquisition Success: Lessons from FirstGroup in North America. European Management Journal, 24(6), 396-410.

Eckert, S., Dittfeld, M., Muche, T., \& Rässler, S. (2010). Does Multinationality Lead to Value Enhancement? An Empirical Examination of Publicly Listed Corporations from Germany. International Business Review, 19(6), 562-574.

Erminio, F., \& Rugman, A. M. (1996). A Test of Internalization Theory and Internationalization Theory: The Upjohn Company. Management International Review, 36(3), 199-215.
Gatignon, H., \& Anderson E. (1988). The Multinational Corporation's Degree of Control over Foreign Subsidiaries: An Empirical Test of a Transaction Cost Explanation. Journal of Law, Economics, and Organization, 4(2), 305-336.

Geringer, J. M., Beamish, P. W., \& Da Costa, R. C. (1989). Diversification Strategy and Internationalization: Implication for MNE Performance. Strategic Management Journal, 10(2), 109-119.

Gomes, L. K., \& Ramaswamy, K. (1999). An Empirical Examination of the Form of the Relationship between Multinationality and Performance. Journal of International Business Studies, 30(1), 173-188.

Grant, R. M. (1987). Multinationality and Performance among British Manufacturing Companies. Journal of International Business Studies, 18(1), 79-89.

Grant, R. M., Jammine, A. P., \& Thomas, H. (1988). Diversity, Diversification and Profitability among British Manufacturing Companies 1972-1984. Academy Management Journal, 31(4), 771-801.

Gupta, A., \& Misra, L. (2000). The Value of Experiential Learning by Organizations: Evidence from International Joint Ventures. Journal of Financial Research, 23(1), 77-102.

Hitt, M., Hoskisson, R., \&.Ireland, R. (1994). A Mid-range Theory of the Interaction Effects of International and Product Diversification on Innovation and Performance. Journal of Management, 20(2), 297-327.

Hufbauer, G. (1970). The Impact of National Characteristics and Technology on the Commodity Composition of Trade in Manufactured Goods. In: Raymond Vernon (Ed.), The Technology Factor in International Trade (pp. 145-231). Boston, MA: NBER. https://www.nber.org/chapters/ c3381

Mansfield, E. (1981). Composition of R and D expenditures: Relationship to Size of Firm, Concentration, and Innovative Output. Review of Economics and Statistics, 63(4), 610-615.

Jones, E., \& Danbolt, J. (2003). R\&D Project Announcements and the Impact of Ownership Structure. Applied Economics Letters, 10(14), 933-936.

Kim. W. C., Hwang, P., \& Burgers, W. P. (1989). Global Diversification Strategy and Corporate Profit Performance. Strategic Management Journal, 10(1), 45-57.

Kogut, B., \& Chang, S. J. (1991). Technological Capabilities and Japanese Foreign Direct Investment in the United States. Review of Economics and Statistics, 73(3), 401-413.

Kotabe, M. (1990). The Relationship between Offshore Sourcing and Innovativeness of US Multinational Firms: An Empirical Investigation. Journal of International Business Studies, 21(4), 623-638.

Kotabe, M., Srinivasan, S. S., \& Aulakh, P. S. (2002). Multinationality and Firm Performance: The Moderating Role of $R \& D$ and Marketing Capabilities. Journal of International Business Studies, 33(1), 70-98.

Lu, J. W., \& Beamish, P. W. (2001). The Internationalization and Performance of SMEs. Strategic Management Journal, 22(6/7), 565-586.

Lu, J. W., \& Beamish, P. W. (2004). International Diversification and Firm Performance: The S-curve Hypothesis. Academy of Management Journal, 47(4), 598-609. 
Meschi, P. X., \& Metais, E. (2006). International Acquisition Performance and Experience: A Resource-based View. Evidence from French Acquisitions in the United States (1988-2004). Journal of International Management, 12(4), 430-448.

Ngo, M. N., Cao, H. H., Nguyen, L. N., \& Nguyen, T. N. (2020). Determinants of Foreign Direct Investment: Evidence from Vietnam. Journal of Asian Finance, Economics and Business, 7(6), 173-183. https://doi.org/10.13106/jafeb.2020.vol7.no6.173

Porrini, P. (2004). Can a Previous Alliance between an Acquirer and a Target Affect Acquisition Performance?. Journal of Management, 30(4), 545-562.

Qian, G. (1994). A Comparative Study of the Risk-Return Performance of US MNEs and DMCs. Doctoral Dissertation. Management School, Lancaster University, Lancashire, England.

Root, F. R. (1994). Entry strategies for international markets, New York, NY: Lexington Books.

Ruigrok, W., \& Wagner, H. (2003). Internationalization and Performance: An Organizational Learning Perspective. Management International Review, 43(1), 63-84.
Tallman, S., \& Li, J. (1996). Effects of International Diversity and Product Diversity on the Performance of Multinational Firms. Academy of Management Journal, 39(1), 179-196.

Taylor, M. L. (1988). Divesting Business Units. Toronto, Canada: Lexington Books.

Tseng, C. H., Tansuhaj, P., Hallagan, W., \& McCullough, J. (2007). Effects of Firm Resources on Growth in Multinationality. Journal of International Business Studies, 38(6), 961-974.

Venkatraman, N., \& Ramanujam, V. (1986). Measurement of Business Performance in Strategy Research: A Comparison of Approaches. Academy of Management Review, 11(4), 801-814.

Vo, Q. T. (2019). Export Performance and Stock Return: A Case of Fishery Firms Listing in Vietnam Stock Market. Journal of Asian Finance, Economics and Business, 6(4), 37-43. https:// doi.org/10.13106/jafeb.2019.vol6.no4.37

Zahra, S. A., Neubaum, D. O., \& Huse, M. (1997). The Effect of the Environment on Export Performance among Telecommunications New Ventures. Entrepreneurship Theory and Practice, 22(1), 25-46. 